\title{
Climate-driven shifts in diatom assemblages recorded in annually laminated sediments of Sacrower See (NE Germany)
}

\author{
E. P. Kirilova $\cdot$ O. Heiri $\cdot$ P. Bluszcz $\cdot$ \\ B. Zolitschka • A. F. Lotter
}

Received: 2 April 2010/Accepted: 13 October 2010/Published online: 4 November 2010

(C) The Author(s) 2010. This article is published with open access at Springerlink.com

\begin{abstract}
Sacrower See is a eutrophic lake with annually laminated sediments extending back to A.D. 1868. Analysis of annual layers revealed multi-decadal periods of distinct diatom assemblages at A.D. 1868-1875, 1876-1940, 1941-1978, and 1979-2000. Detrended correspondence analysis performed on individual seasonal sediment layers showed decadal-scale patterns of turnover in the diatom flora. The spring-summer layers showed higher sample scores until the early 1960s, after which the differences with the autumn-winter layers became smaller. Rates-of-change analysis revealed that the seasonal variability in diatom assemblages was higher than the annual changes. Summer diatom rates of change over the period A.D. 1894-1960 was on average higher than for winter, whereas between the 1960s and 1970s the winter rates of change became higher than the summer ones. Redundancy Analyses showed that seasonal temperatures and wind strength were significant explanatory variables for diatom assemblages in both annual and seasonal layers. These results suggest that meteorological changes indirectly affected diatom assemblages via the mixing regime of the
\end{abstract}

\section{E. P. Kirilova $(\varangle) \cdot$ O. Heiri · A. F. Lotter}

Laboratory of Palaeobotany and Palynology, Palaeoecology, Institute of Environmental Biology, Utrecht University,

Budapestlaan 4, 3584 CD Utrecht, The Netherlands

e-mail: e.p.kirilova@uu.nl

P. Bluszcz · B. Zolitschka

Geopolar, Geomorphology and Polar Research, Institute for Geography, University of Bremen,

Celsiusstr. FVG-M, 28359 Bremen, Germany

O. Heiri

Institute of Plant Sciences and Oeschger Centre for Climate Change Research, University of Bern, Altenbergrain 21, 3013 Bern, Switzerland lake. A comparison of the diatom rates of change with the amplitude of inter-annual climate change shows a statistically significant correlation for the spring-summer layers in the period of A.D. 1963-2000, showing that the sensitivity of diatom assemblages to meteorological changes has varied over the past century, with a stronger effect on diatoms registered during the past 40 years.

Keywords Annually laminated sediments · Varves . Diatoms · Climate

\section{Introduction}

Palaeolimnological analyses of lake sediments provide valuable information on the long-term development of aquatic ecosystems and allow assessing the effects of past natural or human-induced events on lakes and their catchments (Anderson 1993; Teranes et al. 1999; Lotter and Birks 2003; Bradbury et al. 2004). Fossil remains of a range of organisms are preserved in the sediment record and several organism groups are known to be sensitive bioindicators that can be used to reconstruct past environmental conditions. Diatoms are one of the few algal groups that preserve well in lake sediments and have been extensively used in palaeolimnology to track changes in water quality related to changes in $\mathrm{pH}$ or total phosphorus (Hall and Smol 1999; Battarbee et al. 2001). Conventional palaeolimnological studies tend to concentrate on millennial, centennial, or decadal-scale variability of aquatic ecosystems. Besides providing a precise chronological framework, annually laminated (i.e. varved) sediments allow studies at annual or even seasonal resolution. In contrast to physico-chemical approaches such as for instance $\mu \mathrm{XRF}$ scanning (Brauer et al. 2008), however, high-resolution palaeolimnological 
studies based on biotic proxies are scarce, mainly due to the extremely labour-intensive analyses (Peglar 1993; Lotter 1989, 1998; Alefs and Müller 1999).

Since sediments deposited during different parts of the annual cycle are often characterized by layers of different color, texture, and composition, such varved sediments can potentially provide records at a seasonal resolution (Lotter and Lemcke 1999; Teranes et al. 1999). For instance, Lotter et al. (1997) sampled light and dark layers in a freeze-core from Baldeggersee, Central Switzerland, which allowed the separate analysis of parameters such as total organic and inorganic carbon in samples representing spring/summer and autumn/winter, respectively. Similarly, Lotter and Birks (1997) examined the thickness of the light and dark layers in the same sequence and explored the effects of nutrients and regional meteorology on seasonal sedimentation. Besonen et al. (2008) correlated varve thickness with summer temperatures at an annual resolution for the past millennium. Teranes et al. (1999) discussed calcite precipitation in lakes based on geochemical parameters and stable isotopes as well as element ratios of authigenic calcites obtained by sampling of seasonal sediment layers.

Here, we present results of a seasonal-resolution study of 13 decades of diatom deposition in the sediments of Sacrower See, northeastern Germany. The present study is one of the few to analyze diatom assemblages at a seasonal timeresolution in a lake with varved sediments (e.g. Simola et al. 1990). Earlier studies of the Sacrower See sediments examined millennial to centennial-scale changes of diatoms, chironomids, and geochemical proxies, demonstrating the sensitivity of this lake ecosystem to both climate-induced and anthropogenic changes in trophic state during the past 13,000 years (Kirilova et al. 2009; Enters et al. 2010). In the present study, we discuss the variability of diatom assemblages in the youngest, annually laminated section of the Sacrower See record between A.D. 1868 and 2000. First, we examine the multi-decadal variability in diatom assemblages to detect long-term trends in the assemblages. Then, we analyze the inter-annual and inter-seasonal variability in the diatom assemblages to assess the potential of detecting possible meteorological forcing factors for diatom assemblage changes. In the absence of independent data such as, e.g., long-term limnological time-series, it was not possible to disentangle the role of nutrients and climate (see e.g. Lotter and Birks 1997; Lotter 1998).

\section{Study site}

Sacrower See was formed at the end of the Weichselian glaciation and is situated at an elevation of $29.1 \mathrm{~m}$ in Brandenburg, northeastern Germany (Fig. 1). The lake is dimictic,

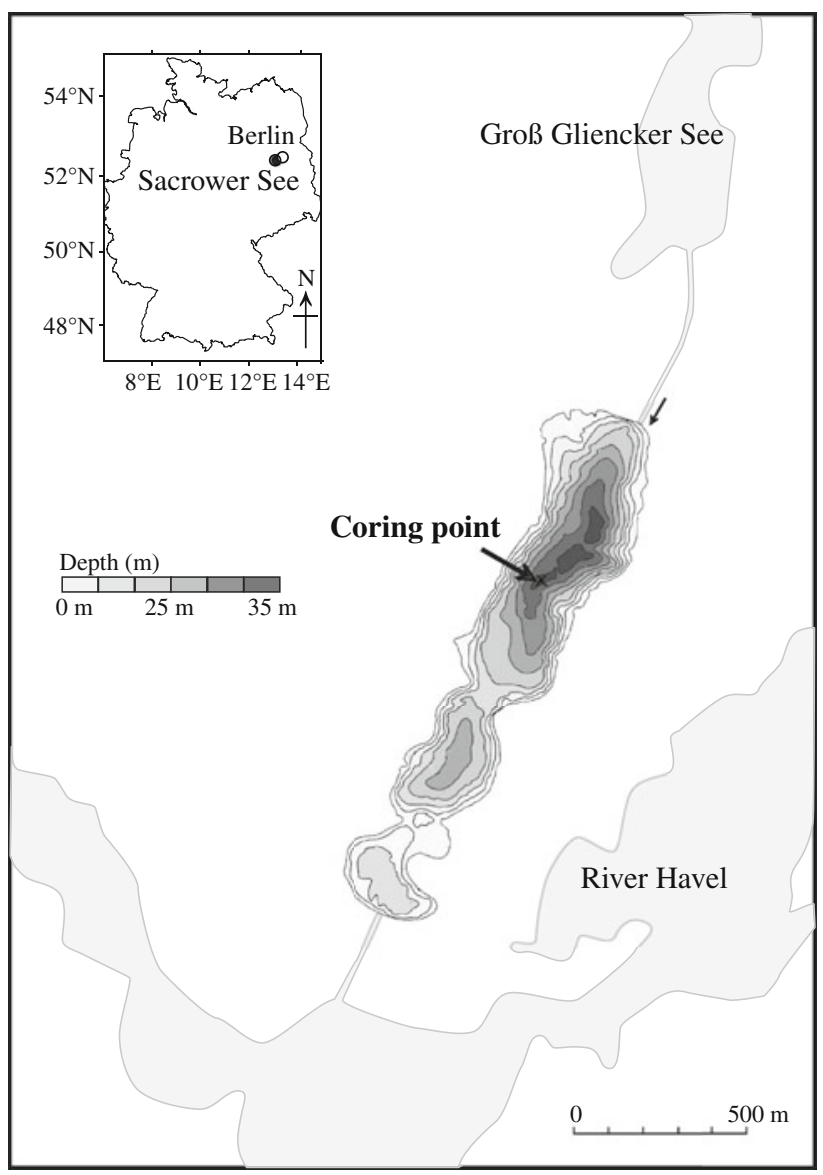

Fig. 1 Location of Sacrower See in northeastern Germany and bathymetric map of the lake basin indicating the coring location

has a maximum depth of $38 \mathrm{~m}$, a catchment area of $35.3 \mathrm{~km}^{2}$, and a surface area of $1.07 \mathrm{~km}^{2}$ (Table 1). The lake's mean water residence time is between 12 and 15 years and the thermocline is usually located between 6 and $8 \mathrm{~m}$ water depth (Bluszcz et al. 2008). Sacrower See has two inlets connecting it with Groß Glienicker See in the North and with the River Havel in the South. In 1986 the connection with the River Havel was obstructed and between 1992 and 1996 the hypolimnion of the lake was artificially aerated. Both actions were aimed at reducing the lake's nutrient load. The eutrophication history of the past century of Sacrower See was reconstructed on an annual timescale based on geochemical parameters (Lüder et al. 2006). Extensive sediment trap studies on the seasonality of modern sedimentation of abiotic and biotic components in Sacrower See have also been conducted (Bluszcz et al. 2008; Kirilova et al. 2008).

\section{Methods}

A $91 \mathrm{~cm}$ long sediment core was recovered from the deepest part of the lake (Fig. 1) using a Niederreiter freeze 
Table 1 Major physico-chemical variables of Sacrower See (after Kirilova et al. 2008)

\begin{tabular}{|c|c|}
\hline Parameter & Value \\
\hline Altitude & $29.5 \mathrm{~m}$ a.s.l. \\
\hline Catchment area & $35.3 \mathrm{~km}^{2}$ \\
\hline Surface area & $1.07 \mathrm{~km}^{2}$ \\
\hline Volume & $19.3 \times 10^{6} \mathrm{~m}^{3}$ \\
\hline Maximum depth & $38 \mathrm{~m}$ \\
\hline Mean depth & $18 \mathrm{~m}$ \\
\hline Minimum width & $250 \mathrm{~m}$ \\
\hline Maximum width & $500 \mathrm{~m}$ \\
\hline Typical epilimnion depth & $7 \mathrm{~m}$ \\
\hline Water residence time & $12-15$ years \\
\hline Typical stratification period & Apr-Nov \\
\hline Annual precipitation & $603 \mathrm{~mm}$ \\
\hline Summer Twater down to $5 \mathrm{~m}$ & $15-20^{\circ} \mathrm{C}$ \\
\hline Winter Twater down to $5 \mathrm{~m}$ & $1-2^{\circ} \mathrm{C}$ \\
\hline $\mathrm{pH}$ & $7-9$ \\
\hline Epilimnetic $\mathrm{PO}_{4}{ }^{3-}$ & $0.01-0.9 \mathrm{mg} \mathrm{L}^{-1}$ \\
\hline Hypolimnetic $\mathrm{PO}_{4}{ }^{3-}$ & $0.6-4.6 \mathrm{mg} \mathrm{L}^{-1}$ \\
\hline Epilimnetic $\mathrm{NO}_{3}{ }^{-}$ & $0.01-0.7 \mathrm{mg} \mathrm{L}^{-1}$ \\
\hline Hypolimnetic $\mathrm{NO}_{3}^{-}$ & $30 \mathrm{mg} \mathrm{L}^{-1}$ \\
\hline Total phosphorus & $0.02-0.16 \mathrm{mg} \mathrm{L}^{-1}$ \\
\hline $\mathrm{SiO}_{2}$ & $0.05-0.42 \mathrm{mg} \mathrm{L}^{-1}$ \\
\hline
\end{tabular}

corer. The upper $44 \mathrm{~cm}$ of the freeze core was annually laminated and suitable for high resolution sampling. The varved sediments of Sacrower See are macroscopically divided into couplets of light and dark layers. The dark layers consist of fine organic matter deposited during autumn and winter, whereas the light layer is composed of planktonic diatoms and calcite crystals precipitated during spring and summer (Lotter 1989; Lotter et al. 1997; Lüder et al. 2006). This annual cycle in sedimentation has been confirmed by a sediment trap study in Sacrower See (Bluszcz et al. 2008; Kirilova et al. 2008).

The chronology of the sediment core is based on varve counts that were crosschecked by ${ }^{137} \mathrm{Cs}$ and ${ }^{210} \mathrm{~Pb}$ dating (Lüder et al. 2006; Bluszcz et al. unpubl. data). Ten specific years (A.D. 1999, 1998, 1961, 1958, 1941, 1942, 1892, 1893,1898 , and 1883) were not included in the diatom analysis because a seasonal sampling was not possible for these years.

Quantitative diatom analyses were conducted for each light and dark layer separately for the period between A.D. 1868 and 2000, and the data are expressed as percentages and diatom accumulation rates (DAR). Organic matter in the seasonal sediment layers was digested by $10 \% \mathrm{H}_{2} \mathrm{O}_{2}$ and microscope slides were made using the sedimentation tray method (Battarbee 1973). The diatoms were identified following (Krammer and Lange-Bertalot 1986, 1988, 1991a, b),
Håkansson (2002), Round et al. (1990), and Compère (2001). Diatom assemblage zones were defined based on percentage data by optimal sum of squares partitioning (Birks and Gordon 1985) using the program ZONE (Lotter and Juggins 1991). The statistically significant number of zones was assessed by applying a broken stick model (Bennett 1996).

Detrended correspondence analysis (DCA), principal component analysis (PCA), and redundancy analysis (RDA) were carried out with the software CANOCO 4.51 (ter Braak and Šmilauer 1998). Biostratigraphic ratesof-change analyses used chord distance as a dissimilarity measure between adjacent diatom samples (see Lotter et al. 1992; Lotter 1998).

\section{Results and discussion}

Multi-decadal diatom variability

Diatom assemblages in the varved section of Sacrower See showed a dominance of diatoms typical for eutrophic lakes (Lotter 1998; Bradbury et al. 2004; Hausmann and Kienast 2006) (Fig. 2). Numerical zonation of the diatom assemblages divided the record into four statistically significantly periods (D1-D4), indicating a clear multi-decadal variability (see Fig. 2). Stephanodiscus parvus, a diatom with hypertrophic affinities, was recorded in high relative abundances throughout the whole record. However, from A.D. 1868-1875 (D1) S. parvus was accompanied by Cyclotella comensis, a diatom with mesotrophic affinities that was present in higher abundances in Sacrower See throughout large parts of the Holocene (Kirilova et al. 2009). From A.D. 1876 to the 1940s (D2), the main diatoms were Stephanodiscus spp. (S. parvus, S. alpinus, and S. neoastraea). Aulacoseira islandica was abundant before A.D. 1905, recorded at lower abundances until ca. A.D. 1930, and largely absent from the sediments thereafter. In the period A.D. 1941-1978 (D3), Stephanodiscus alpinus decreased in abundance. At the same time, Cyclostephanos dubius increased, suggesting a slight decrease in nutrient concentrations (Anderson 1990). From A.D. 1979-2000, the assemblages were dominated by $S$. parvus. Aulacoseira subarctica appeared for the first time in higher abundances around A.D. 1980 together with increased values of Asterionella formosa.

Inter-annual and inter-seasonal diatom variability

The diatom assemblages (Fig. 2) in the varved section of the Sacrower See sediments indicate decadal-scale stability of the assemblages as often observed in palaeolimnological studies, but they also show clear dynamic fluctuations in the diatom flora at shorter time scales. Such short-term 


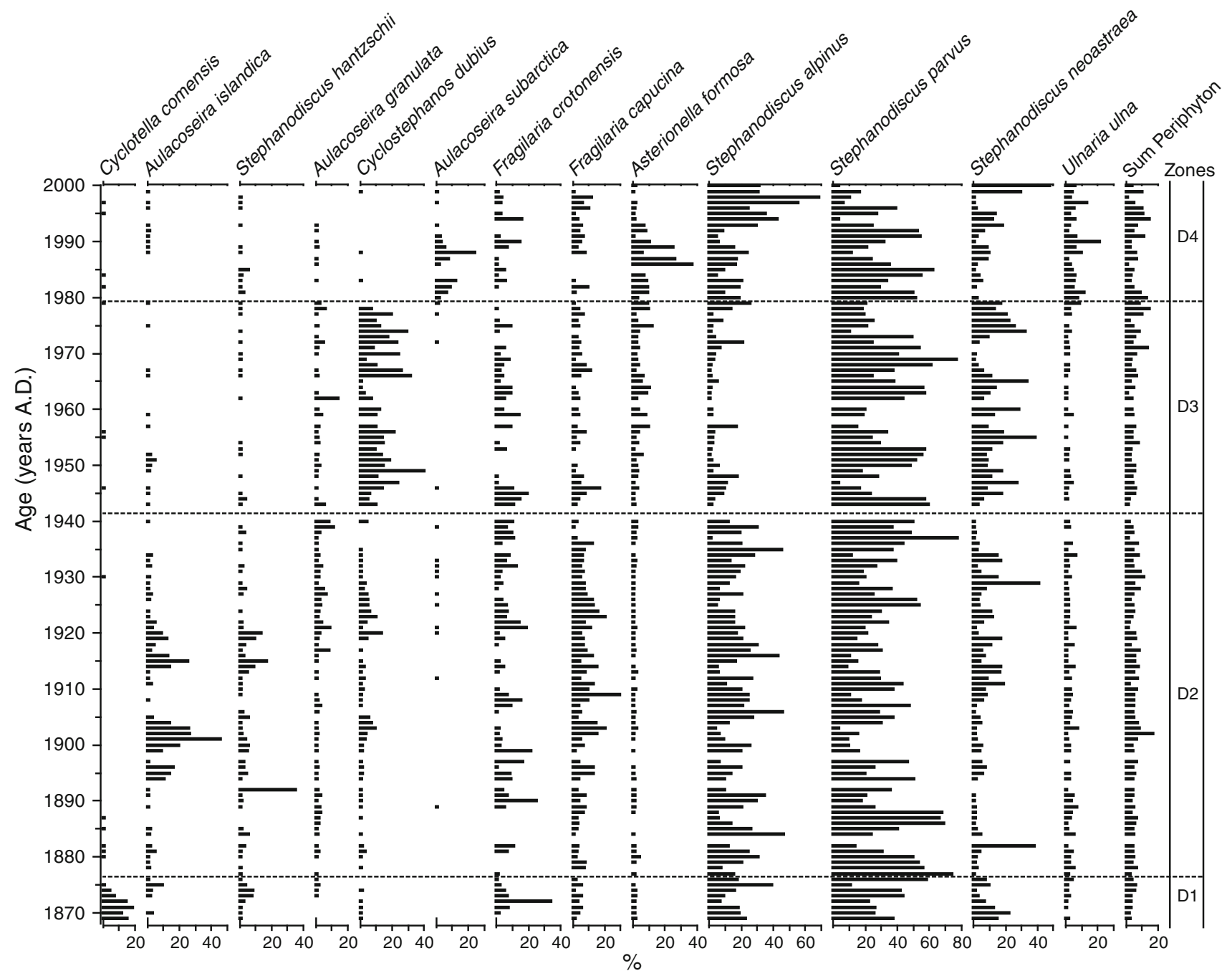

Fig. 2 Annually resolved record of diatom assemblages (expressed as percentages of total diatoms) in Sacrower See between A.D. 1868 and 2000. Only selected taxa are shown

fluctuations as recorded in the annual and seasonal layers of Sacrower See allow an examination of assemblage dynamics and a comparison with meteorological data at the temporal resolution of sediment traps (Kirilova et al. 2008) or even at the resolution of limnological monitoring data (e.g. Lotter and Psenner 2004). Due to the lack of regional meteorological data before A.D. 1894, numerical analysis of the dynamics of diatom changes and their relationship with environmental factors at inter-annual and inter-seasonal resolution was restricted to the time span A.D. 1894-2000.

To eliminate the effects of closure on the percentage data, we also expressed the results as diatom accumulation rates (DAR, i.e. number of valves $\mathrm{cm}^{-2}$ season $^{-1}$ ). Figure 3 shows the DAR for the period A.D. 1894-2000 at a seasonal resolution with each light (spring-summer) and dark (autumn-winter) layer analyzed separately. The succession of diatoms at seasonal resolution (Fig. 3) is comparable to the record presented at annual resolution
(Fig. 2). As expected, the inter-annual differences in DAR are more striking than in the percentage data. Overall, $S$. parvus is clearly the most productive diatom with regard to the DAR. Surprisingly, there is no clear seasonal pattern in diatom accumulations between the seasonal layers, neither in the early blooming diatoms (e.g. S. parvus), nor in the summer bloomers (e.g. Fragilaria crotonensis, Ulnaria ulna) (Table 2; Figs. 3, 4). This is likely the result of blooms of planktonic diatoms such as Stephanodiscus and Asterionella during the autumn and winter season as also indicated by the sediment trap results (Kirilova et al. 2008). Moreover, resuspension of sediment and diatoms during autumn and winter as also evidenced in the sediment trap study of Bluszcz et al. (2008) can partly account for this phenomenon. In general, the spring-summer (light) layers showed slightly higher overall DAR (Table 2; Fig. 4), as expected, because they represent the diatom productivity during the growing season of planktonic taxa. 


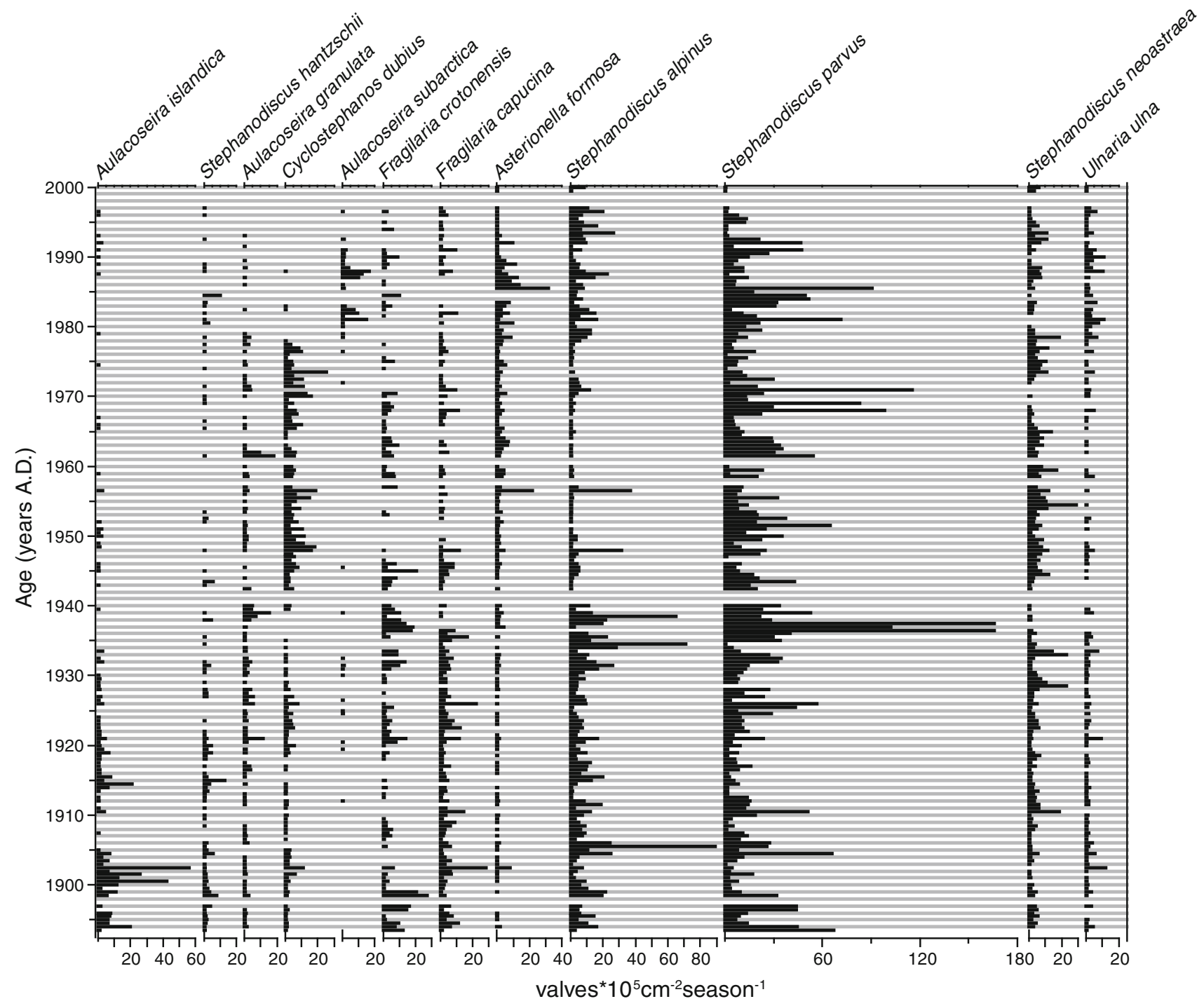

Fig. 3 Diatom accumulation rates (valves $\times 10^{5} \mathrm{~cm}^{-2}$ season ${ }^{-1}$ ) for the dark (autumn-winter) and light (spring-summer) layers of the varved sediments of Sacrower See. The grey lines indicate the dark (autumn/winter) layers in the varved sediments. Only selected taxa are shown

Table 2 Mean diatom accumulation rates (valves $\times 10^{5}$ valves $\mathrm{cm}^{-2}$ season $^{-1}$ ) and standard deviations for periphytic and planktonic life forms as well as for the total diatom accumulation rates in the light and dark layers of Sacrower See during different periods of the annually laminated sediment record

\begin{tabular}{|c|c|c|c|c|c|c|}
\hline \multirow[t]{2}{*}{ Period (A.D.) } & \multicolumn{2}{|l|}{ Periphyton } & \multicolumn{2}{|l|}{ Plankton } & \multicolumn{2}{|l|}{ Total } \\
\hline & Light & Dark & Light & Dark & Light & Dark \\
\hline 1894-2000 & $2.84 \pm 2.70$ & $2.67 \pm 3.95$ & $46.82 \pm 36.19$ & $41.00 \pm 28.84$ & $49.65 \pm 37.41$ & $43.67 \pm 30.93$ \\
\hline 1894-1940 & $3.45 \pm 3.16$ & $2.45 \pm 1.96$ & $53.65 \pm 45.65$ & $42.20 \pm 29.96$ & $57.10 \pm 46.99$ & $44.64 \pm 30.74$ \\
\hline 1941-1978 & $2.52 \pm 2.15$ & $2.84 \pm 6.01$ & $43.19 \pm 22.92$ & $40.68 \pm 29.40$ & $45.71 \pm 24.44$ & $43.51 \pm 33.68$ \\
\hline 1979-2000 & $1.99 \pm 2.23$ & $2.88 \pm 2.47$ & $37.49 \pm 29.23$ & $38.77 \pm 26.28$ & $39.48 \pm 29.29$ & $41.65 \pm 27.23$ \\
\hline
\end{tabular}

In an attempt to study the floristic turnover in the diatom dataset and to examine whether diatoms deposited during spring-summer (light layer) and autumn-winter (dark layer) record comparable assemblage changes, we applied a series of DCAs to the square-root transformed diatom percentages from the light and the dark layers separately. The sample scores on the first DCA axis (gradient lengths: light layer 1.6; dark layer 1.5 SD units) recorded very 


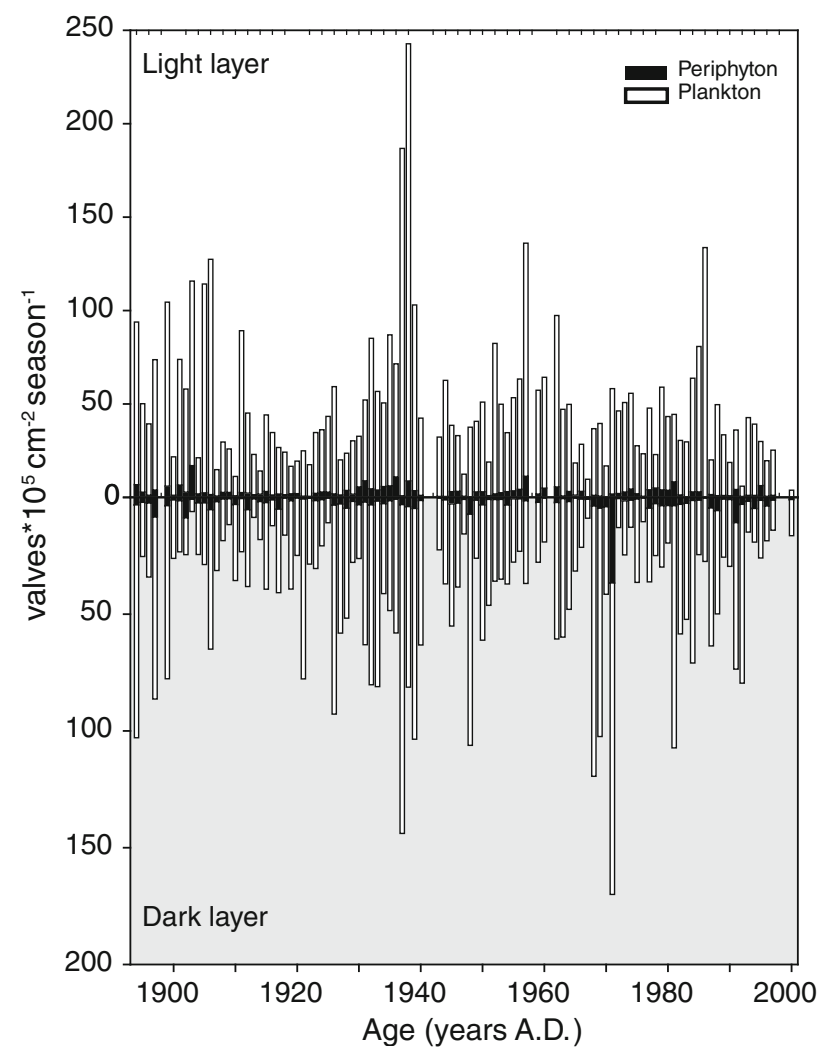

Fig. 4 Accumulation rates (valves $\times 10^{5} \mathrm{~cm}^{-2}$ season $^{-1}$ ) of planktonic and periphytic diatoms in the light (spring-summer) and dark (autumn-winter) layers of Sacrower See between A.D. 1894 and 2000

similar trends in the data (Fig. 5). Samples from A.D. 1894 to the 1930s are characterized by high scores, samples deposited between the 1930s and the 1980s by lower scores, and samples since the 1990s again by increased DCA scores (Fig. 5). At decadal time-scales, the 1st DCA axis sample scores of both types of layers showed in general a similar pattern (Fig. 5). However, there were some differences, such as the generally higher samples scores of the light layers until the early 1960s, or individual years in which light and dark layers registered opposing trends in DCA axis 1 scores (e.g. A.D. 1938, 1982). Since the 1960s, however, the differences between the sample scores of the two seasonal layers were much smaller than in earlier samples and the curves generally run parallel (Fig. 5).

The rates-of-change analyses between diatom assemblages in the annual as well in the seasonal layers indicated that the variability between seasons (i.e. between the diatoms in the light and dark layers) was generally slightly higher than the inter-annual variability (Fig. 6a). This higher between-season variability can be explained by the typical seasonal succession in the diatom flora as also evidenced by sediment trap studies in Sacrower See (Kirilova et al. 2008), whereas the lower inter-annual variability is mainly due to

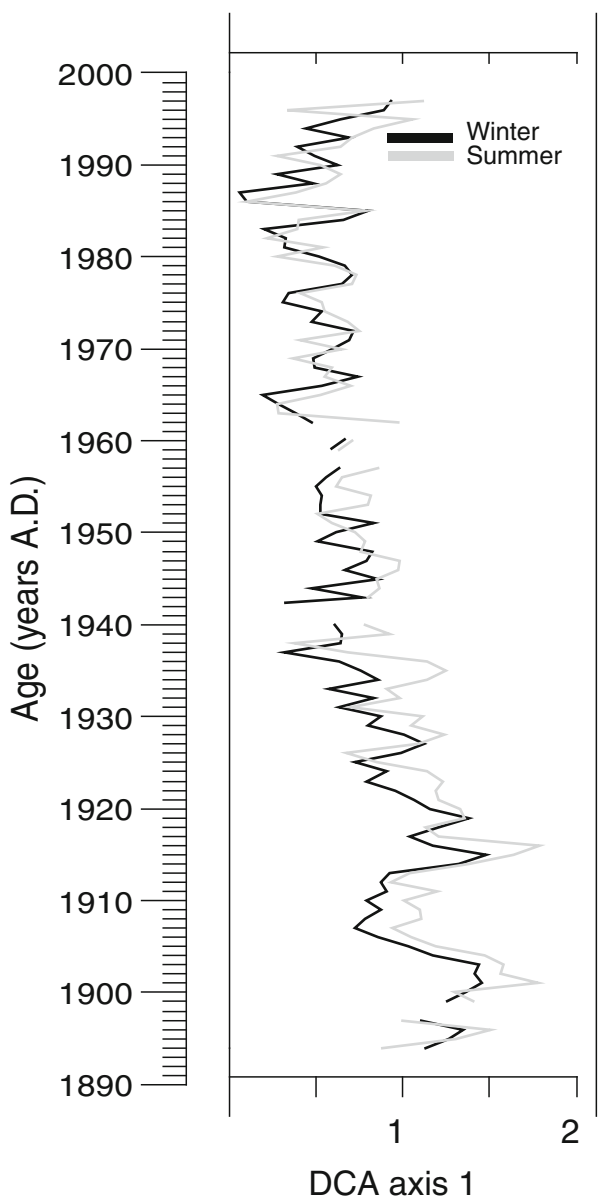

Fig. 5 Sample scores of detrended correspondence analyses (DCA) axis 1 (in standard deviation units) of diatom assemblages calculated separately for light (spring-summer) and dark (autumn-winter) seasonal layers in the Sacrower See varve record

the overprinting dominance of $S$. parvus over the whole period (Fig. 2).

If we analyze the rates of change between subsequent light layers or subsequent dark layers (Fig. 6b) to assess season-to-season variability (i.e. spring-summer versus spring-summer or autumn-winter vs. autumn-winter), the rates of change were generally comparable, pointing to similar diatom responses in the different seasons as already seen in the seasonal DAR (Fig. 3). However, the summer rates of change in the period A.D. 1894-1960 were on average higher than the winter ones, whereas between the 1960s and 1970s the winter rates of change become higher than the summer ones (Fig. 6).

\section{Diatom dynamics in relation to climate}

In lakes, the taxonomic composition and the abundance of diatoms during the seasonal cycle are generally dependent on factors such as the availability of nutrients (e.g. Si, P, N), the stratification of the water column, as well as light and 
Fig. 6 Rates-of-change (ROC) analyses of diatom assemblages as expressed by the chord distance between layers. a Annual (i.e. between varves) and seasonal (i.e. between consecutive light and dark layers) rates of change.

b Autumn/winter (i.e. between consecutive dark layers) and spring/summer (i.e. between consecutive light layers) rates of change

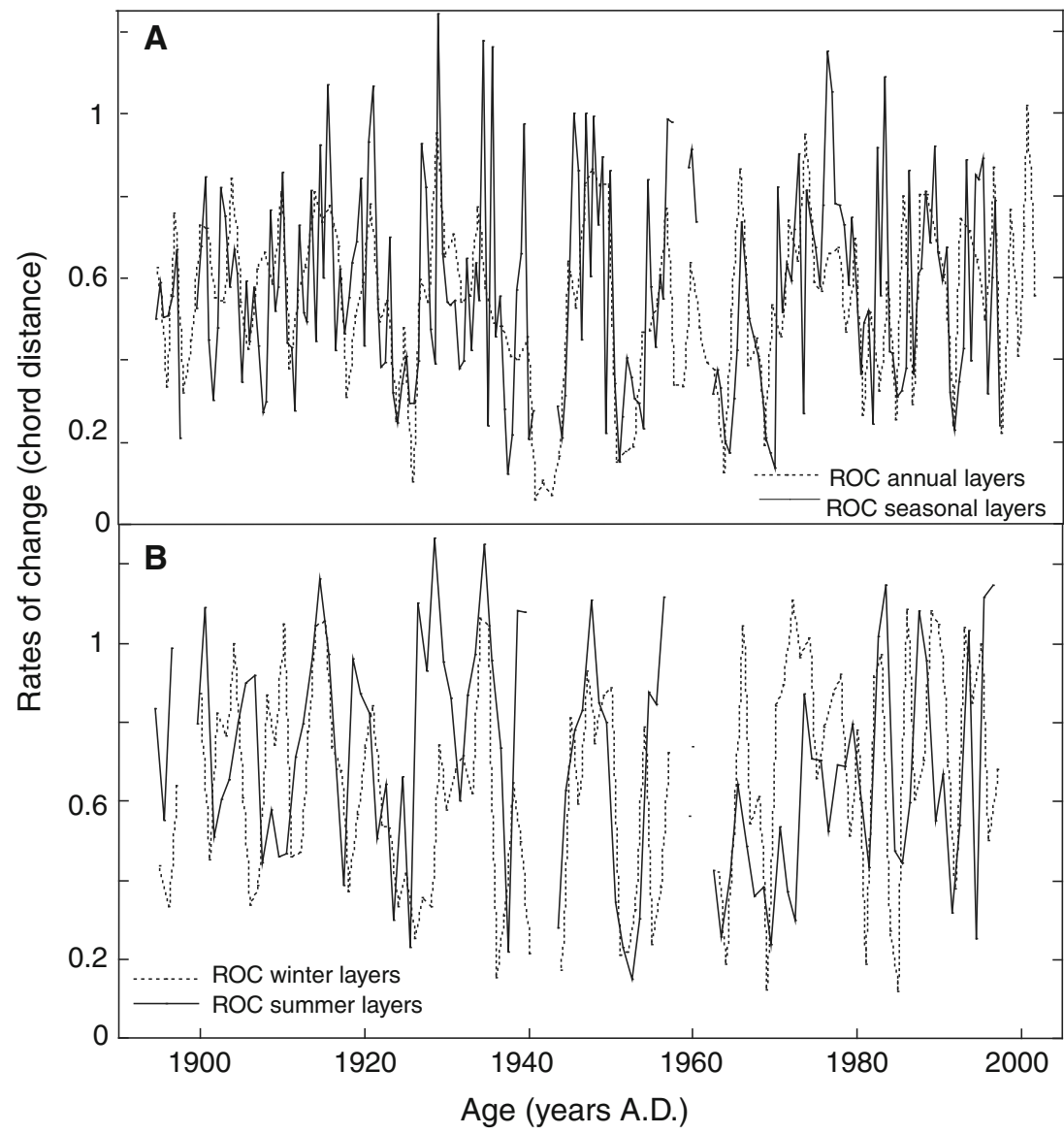

Table 3 Redundancy analysis (RDA) of relative diatom abundances in the annual, the light (spring/summer), and the dark (autumn/winter) layers

\begin{tabular}{|c|c|c|c|c|c|c|}
\hline & \multicolumn{2}{|c|}{ Annual assemblages } & \multicolumn{2}{|c|}{ Spring/summer assemblages } & \multicolumn{2}{|c|}{ Autumn/winter assemblages } \\
\hline & $1894-2000$ & $1963-2000$ & $1894-2000$ & 1963-2000 & 1894-2000 & 1963-2000 \\
\hline $\begin{array}{l}\text { Variance explained by forward selected } \\
\text { predictors }\end{array}$ & $4 \%$ & $12.1 \%$ & $4.3 \%$ & $27.8 \%$ & $4.1 \%$ & $6.3 \%$ \\
\hline \multirow[t]{4}{*}{ Forward selected predictors } & Wind $* *$ & Tmean** & Wind MAM* & Tmin DJF** & Wind JJA* & Sun JJA* \\
\hline & Tmean* & Wind* & Tmin JJA* & Tmin $\mathrm{JJA}^{* *}$ & Tmin JJA* & \\
\hline & & & & Wind MAM** & & \\
\hline & & & & Tmax JJA* & & \\
\hline
\end{tabular}

Analysis of annual layers included mean annual sunshine duration, temperature, precipitation, snow deposition, and wind strength as explanatory variables. The seasonal layers were analyzed with seasonal means of temperature (Tmean), minimum temperature (Tmin), maximum temperature (Tmax), daily sunshine duration (Sun), precipitation (PP), snow deposition, and wind strength as environmental predictors. Light (spring/ summer) layer diatoms were compared with mean spring (MAM) and summer (JJA) values as well as environmental conditions during the preceding winter (DJF), whereas dark (autumn/winter) layer diatoms were compared with autumn (SON) and winter conditions as well as with parameters measured during the preceding summer

* Significant at the 0.05 level as assessed by 9,999 restricted Monte Carlo permutations

** Significant at the 0.01 level as assessed by 9,999 restricted Monte Carlo permutations

temperature (Kilham et al. 1996; Köster and Pienitz 2006; Kirilova et al. 2008). In an attempt to identify the factors that drive the annual and seasonal changes in the composition of the diatom assemblages in Sacrower See, we carried out a series of RDAs with forward selection of climatic parameters as independent explanatory variables that explain a statistically significant amount $(\mathrm{P}<0.05)$ of the variance in the diatom data (Table 3). A rather small amount of variance in diatom assemblages in the annual layers (4\%) can be explained by mean annual temperature and mean annual wind strength. Bluszcz et al. (unpubl. data) have shown a distinct change of $\delta^{18} \mathrm{O}$ and $\delta^{13} \mathrm{C}$ values of the precipitated 
calcites after the 1960s, which became more positive in the light spring-summer than in the dark autumn-winter layers, suggesting a higher sensitivity of Sacrower See to meteorological changes. If we restrict the analysis to the time-span between A.D. 1963-2000, during which we also observed changes in the patterns of floristic turnover and rates of change (Figs. 5, 6), both climatic predictors together explained $12.1 \%$ of the variance in the diatom assemblages (Table 3). The RDA with forward selection for the light (spring-summer) layers showed that mean spring wind strength and minimum summer temperatures explain a statistically significant amount of the variance in the diatom data of the whole time-series. If restricted to the period of A.D. 1963-2000, these variables together with additional explanatory variables such as minimum temperatures of the preceding winter and maximum summer temperatures explained $27.8 \%$ of the variance. Wind strength and summer-winter temperatures have a strong effect on spring mixis and the stability of summer and winter stratification of lakes. Our results therefore suggest that meteorological changes indirectly affected diatom assemblages via the mixing behavior of the lake. The RDA of the dark (autumnwinter) layers showed that mean wind strength during summer as well as minimum summer temperatures explained a small part (4.1\%, Table 3$)$ of the variance of the whole series, whereas summer sunshine duration explained $6.3 \%$ in the shorter series.

The main factor controlling the spring diatom bloom is the onset of the growing season, which for diatoms usually is the time of the spring mixing. Peeters et al. (2007a, b) related an earlier onset of lake stratification to warmer climate and demonstrated that increased winter and spring air temperatures go together with an earlier onset of the spring phytoplankton bloom in Lake Constance. Bluszcz et al. (2008; unpubl. data) suggested that the more positive NAO regime since the 1960s, resulting in an earlier onset of wet and warm winters, has affected the duration of lake stratification in Sacrower See. Moreover, Peeters et al. (2007a) showed that increased air temperature in the late summer reduced the duration of homothermy of Lake Constance in autumn and thus resulted in a longer stratification period. However, since A.D. 1963, nutrient input into Sacrower See increased (Lüder et al. 2006), which could also cause the shifts in the diatom assemblages.

The different rates of change results (Fig. 6) suggest that the dynamics in the short-term diatom assemblage changes may have been influenced by the amplitude of inter-annual climate change. To test this, we carried out a PCA of selected climatic variables (see Table 4) and calculated the difference between adjacent PCA sample scores (analogous to the rates of change in the diatom data) to approximate the inter-annual or seasonal amplitude of climate change. Rates of change between years and seasons were then
Table 4 Correlation of rates-of-change in diatom assemblages with amplitudes of inter-annual and inter-seasonal changes in climatic conditions

\begin{tabular}{|c|c|c|c|}
\hline & \multicolumn{2}{|c|}{ PCA axis 1} & \multirow[t]{2}{*}{$\mathrm{n}$} \\
\hline & $\mathrm{r}$ & $\mathrm{p}$ & \\
\hline \multicolumn{4}{|c|}{ Year to year changes } \\
\hline 1894-2000 & 0.07 & 0.42 & 100 \\
\hline $1963-2000$ & 0.13 & 0.30 & 65 \\
\hline \multicolumn{4}{|c|}{ Spring/summer to spring/summer changes } \\
\hline 1894-2000 & 0.04 & 0.70 & 94 \\
\hline $1963-2000$ & 0.34 & $0.05 *$ & 34 \\
\hline \multicolumn{4}{|c|}{ Autumn/winter to autumn/winter changes } \\
\hline 1894-2000 & -0.12 & 0.24 & 94 \\
\hline $1963-2000$ & -0.22 & 0.24 & 34 \\
\hline
\end{tabular}

Climatic changes have been summarized by principal compenent analysis (PCA) and amplitudes of climatic change were expressed as variations in PCA axis 1 scores. The following climate variables were used for annual rates of change: Sun h, Tmax, Tmean, Tmin, PP, Snow, Wind. Dark layer (autumn/winter): SunDJF, SunSON, TmaxDJF, TmaxSON, TmeaDJF, TmeaSON, TminDJF, TminSON, ppDJF, ppSON, SnowDJF, SnowSON, WindDJF, WindSON. Light layer (spring/summer): SunMAM, SunJJA, TmaxMAM, TmaxJJA, TmeaMAM, TmeaJJA, TminMAM, TminJJA, ppMAM, ppJJA, SnowMAM, SnowJJA, WindMAM, WindJJA

* Significant at the 0.05 level

correlated with the diatom rates of change. This analysis was carried out for the entire time-series (inter-annual) as well as for the light and dark sublayers separately, reflecting the changes between consecutive spring-summer or autumn-winter periods (inter-seasonal). The results (Table 4) showed that there were no statistically significant correlations between the diatom rates of change and the amplitude of inter-annual or inter-seasonal climate change with the exception of the diatom rates of change for the spring-summer layers for the period of A.D. 1963-2000.

\section{Conclusions}

Our study of diatom assemblages in Sacrower See at a seasonal resolution demonstrated that diatoms deposited in spring-summer and autumn-winter reflect very similar assemblage changes, especially at multi-annual to decadal time-scales. Separate analyses of the diatoms in the light and the dark layers produced very similar ordination results. Moreover, our results indicate that the influence of meteorological parameters such as temperature and wind can be traced back in diatom studies, of varved sequences at a seasonal basis. In the case of Sacrower See, our analysis clearly indicates a stronger influence of meteorology on diatom assemblages during spring-summer than during autumn-winter. Furthermore, the results suggest 
that the sensitivity of diatom assemblages to meteorological changes and nutrient increase has varied over the past ca. 120 years in Sacrower See, with a stronger effect on diatoms registered since the 1960s. Our results show that seasonally resolved diatom records may better reflect shortterm meteorological changes than annual records and may therefore provide a promising avenue for future climate reconstructions based on varved sediment records.

Acknowledgments We wish to express our gratitude to Dirk Enters, Torsten Haberzettl, Britta Lüder, Stephanie Kastner, Michael Fey, Herbert Ebel, Uwe Brämick, Frank Rümmler, Steffen Zienert, Jens Mingram, Achim Brauer, and Michael Köhler for help during fieldwork. Michael Kriews and Fernando Valero-Delgado from the Alfred Wegener Institute, Bremerhaven provided cold rooms and a band saw for sampling. We thank Michael Köhler also for the preparation of the thin sections. Hermann Oesterle and Friedrich-Wilhelm Gerstengarbe provided the meteorological data from the meteorological station at Potsdam-Telegrafenberg. We acknowledge the support by the Utrecht Centre of Geosciences (UCG) and the Centre for Wetland Ecology (CWE). This is Netherlands Research School of Sedimentary Geology (NSG) publication no. 20101001.

Open Access This article is distributed under the terms of the Creative Commons Attribution Noncommercial License which permits any noncommercial use, distribution, and reproduction in any medium, provided the original author(s) and source are credited.

\section{References}

Alefs J, Müller J (1999) Differences in the eutrophication dynamics of Ammersee and Starnberger See (Southern Germany), reflected by the diatom succession in varved sediments. J Paleolimnol 21:395-407

Anderson NJ (1990) The biostratigraphy and taxonomy of small Stephanodiscus and Cyclostephanos species (Bacillariophyceae) in a European lake, and their ecological implications. Br Phycol J 25:217-235

Anderson RY (1993) The varve chronometer in Elk Lake: record of climate variability and evidence of solar-geomagnetic- ${ }^{14} \mathrm{C}$ climate connection. In: Bradbury JP, Dean WE (eds) Elk Lake, Minnesota: evidence for rapid climate change in the North Central United States, vol 276. Geological Society of America Special Paper, Boulder, p 45-67

Battarbee RW (1973) A new method for estimating absolute microfossil numbers with special reference to diatoms. Limnol Oceanogr 18:647-653

Battarbee RW, Jones VJ, Flower RJ, Cameron NJ, Bennion H, Carvalho L, Juggins S (2001) Diatoms as indicators of surface water acidity. In: Smol JP, Birks HJB, Last WM (eds) Tracking environmental changes using lake sediments: terrestrial, algal, and siliceous indicators, vol 3. Kluwer Academic Publishers, The Netherlands, pp 155-203

Bennett KD (1996) Determination of the number of zones in a biostratigraphical sequence. N Phytol 132:155-170

Besonen MR, Patridge W, Bradley RS, Francus P, Stoner JS, Abbott MB (2008) A record of climate over the last millennium based on varved lake sediments from the Canadian High Arctic. The Holocene 18:169-180

Birks HJB, Gordon AD (1985) Numerical methods in Quaternary pollen analysis. Academic Press, London
Bluszcz P, Kirilova E, Lotter AF, Ohlendorf C, Zolitschka B (2008) Global radiation and onset of stratification as forcing factors of seasonal carbonate and organic matter flux dynamics in a hypertrophic hardwater lake (Sacrower See, Northeastern Germany). Aquat Geochem 14:73-98

Bradbury PJ, Colman SM, Reynolds R (2004) The history of recent limnological changes and human impact on Upper Klamath Lake, Oregon. J Paleolimnol 31:151-165

Brauer A, Haug GH, Dulski P, Sigman DM, Negendank JFW (2008) An abrupt wind shift in Western Europe at the onset of the Younger Dryas cold period. Nat Geosci 1:520-523

Compère P (2001) Ulnaria (Kützing) Compère, a new genus name for Fragilaria subgen. Alterasynedra Lange-Bertalot with comments on the typification of Synedra Ehrenberg. In: Jahn R, Kociolek JP, Witkowski A, Compère P (eds) Lange-BertalotFestschrift. Studies on Diatoms. A.R.G. Ganther Verlag KG, Ruggell, pp 97-101

Enters D, Kirilova E, Lotter AF, Lücke A, Parplies J, Kuhn G, Jahns S, Zolitschka B (2010) Climate change and human impact at Sacrower See (NE Germany) during the past 13, 000 years: a geochemical record. J Palaeolimnol 23:719-737

Håkansson H (2002) A compilation and evalutation of species in the general Stephanodiscus, Cyclostephanos and Cyclotella with a new genus in the family Stephanodiscaceae. Diatom Research 17:1-139

Hall RI, Smol JP (1999) Diatoms as indicators of lake eutrophication. In: Stoermer EF, Smol JP (eds) The diatoms: application for the environmental and earth sciences. Cambridge University press, London, pp 128-168

Hausmann S, Kienast F (2006) A diatom-inference model for nutrients screened to reduce the influence of background variables: application to varved sediments of Greifensee and evaluation with measured data. Palaeogeogr Palaeoclimatol Palaeoecol 233:96-112

Kilham SS, Theriot EC, Fritz SC (1996) Linking planktonic diatoms and climate in the large lakes of the Yellowstone ecosystem using resource theory. Limnol Oceanogr 41:1052-1062

Kirilova EP, Bluszcz P, Heiri O, Cremer H, Ohlendorf C, Lotter AF, Zolitschka B (2008) Seasonal and interannual dynamics of diatom assemblages in Sacrower See (NE Germany): a sediment trap study. Hydrobiologia 614:159-170

Kirilova E, Heiri O, Enters D, Cremer H, Lotter AF, Zolitschka B, Hübener T (2009) Climate-induced changes in the trophic status of a Central European lake. J Limnol 68:71-82

Köster K, Pienitz R (2006) Seasonal diatom variability and paleolimnological inferences-a case study. J Paleolimnol 35:395-416

Krammer K, Lange-Bertalot H (1986) Bacillariophyceae. 1. Teil: Naviculaceae. Spektrum Akademischer Verlag, Heidelberg

Krammer K, Lange-Bertalot H (1988) Bacillariophyceae. 2. Teil: Bacillariaceae, Epithemiaceae, Surirellaceae. Spektrum Akademischer Verlag, Heidelberg

Krammer K, Lange-Bertalot H (1991a) Bacillariophyceae. 3. Teil: Centrales, Fragilariaceae, Eunotiaceae. Spektrum Akademischer Verlag, Heidelberg

Krammer K, Lange-Bertalot H (1991b) Bacillariophyceae. 4. Teil: Achnanthaceae, kritische Ergänzungen zu Navicula (Lineolatae) und Gomphonema. Gesamtliteraturverzeichnis Teil 1-4. Spektrum Akademischer Verlag, Heidelberg

Lotter AF (1989) Evidence of annual layering in Holocene sediments of Soppensee, Switzerland. Aquat Sci 51:19-30

Lotter AF (1998) The recent eutrophication of Baldeggersee (Switzerland) as assessed by fossil diatom assemblages. The Holocene 8:395-405

Lotter AF, Birks HJB (1997) The separation of the influence of nutrients and climate on the varve time-series of Baldeggersee, Switzerland. Aquat Sci 59:362-375 
Lotter AF, Birks HJB (2003) The Holocene palaeolimnology of Sägistalsee and its environmental history-a synthesis. J Paleolimnol 30:333-342

Lotter AF, Juggins S (1991) POLPROF, TRAN and ZONE: programs for plotting, editing and zoning pollen and diatom data. Inquasubcommission for the study of the Holocene, Working Group on Data-Handling Methods. Newsletter 6:4-6

Lotter AF, Lemcke G (1999) Methods for preparing and counting biochemical varves. Boreas 28:243-252

Lotter AF, Psenner R (2004) Global change impacts on mountain waters: lessons from the past to help define monitoring targets for the future. In: Lee C, Schaaf T (eds) Global environmental and social monitoring. UNESCO, Paris, pp 102-114

Lotter AF, Ammann B, Sturm M (1992) Rates of change and chronological problems during the late-glacial period. Clim Dyn 6:233-239

Lotter AF, Sturm M, Teranes JL, Wehrli B (1997) Varve formation since 1885 and high-resolution varve analyses in hypertrophic Baldeggersee (Switzerland). Aquat Sci 59:304-325

Lüder B, Kirchner G, Lücke A, Zolitschka B (2006) Palaeoenvironmental reconstrucitons based on geochemical parameters from annually laminated sediments of Sacrower See (northeastern Germany) since the 17th century. J Paleolimnol 35:897-912

Peeters F, Straile D, Lorke A, Livingstone D (2007a) Earlier onset of the spring phytoplankton bloom in lakes of the temperate zone in a warmer climate. Glob Chang Biol 13:1898-1909
Peeters F, Straile D, Lorke A, Ollinger D (2007b) Turbulent mixing and phytoplankton spring bloom development in a deep lake. Limnol Oceanogr 51:286-298

Peglar SM (1993) The mid-Holocene Ulmus decline at Diss Mere, Norfolk, U.K.: a year-by-year pollen stratigraphy from annual laminations. The Holocene 3:1-13

Round FE, Crawford R, Mann D (1990) The Diatoms. Biology and morphology of the genera. Cambridge University Press, Cambridge, p 653

Simola H, Hanski I, Liukkonen M (1990) Stratigraphy, species richness and seasonal dynamics of plankton diatoms during 418 years in Lake Lovojärvi, South Finland. Ann Bot Fennici 27:241-259

Ter Braak CJF, Šmilauer P (1998) CANOCO reference manual and user's guide to CANOCO for windows: software for canonical community ordination (version 4). Microcomp Power Ithaca, NY, p 351

Teranes JL, McKenzie JA, Lotter AF, Sturm M (1999) Stable isotope response to lake eutrophication: calibration of high resolution lacustrine sequence from Baldeggersee, Switzerland. Limnol Oceanogr 44:320-333 